ORIGINAL ARTICLE

\title{
Risk factors for cutaneous malignant melanoma among aircrews and a random sample of the population
}

\author{
V Rafnsson, J Hrafnkelsson, H Tulinius, B Sigurgeirsson, J Hialtalin Olafsson
}

Occup Environ Med 2003;60:815-820

See end of article for authors' affiliations

.....................

Correspondence to: Dr V Rafnsson, Department of Preventive Medicine, University of Iceland, Soltun 1, 105 Reykjavik, Iceland; vilraf@hi.is

Accepted 2 October 2002

\begin{abstract}
Aims: To evaluate whether a difference in the prevalence of risk factors for malignant melanoma in a random sample of the population and among pilots and cabin attendants could explain the increased incidence of malignant melanoma which had been found in previous studies of aircrews.

Methods: A questionnaire was used to collect information on hair colour, eye colour, freckles, number of naevi, family history of skin cancer and naevi, skin type, history of sunburn, sunbed, all sunscreen use, and number of sunny vacations.

Results: The 239 pilots were all males and there were 856 female cabin attendants, which were compared with 454 males and 1464 females of the same age drawn randomly from the general population. The difference in constitutional and behavioural risk factors for malignant melanoma between the aircrews and the population sample was not substantial. The aircrews had more often used sunscreen and had taken more sunny vacations than the other men and women. The predictive values for use of sunscreen were 0.88 for pilots and 0.85 for cabin attendants and the predictive values for sunny vacation were 1.36 and 1.34 respectively.

Conclusion: There was no substantial difference between the aircrew and the random sample of the population with respect to prevalence of risk factors for malignant melanoma. Thus it is unlikely that the increased incidence of malignant melanoma found in previous studies of pilots and cabin attendants can be solely explained by excessive sun exposure.
\end{abstract}

$M$ alignant melanoma has been found in excess among commercial pilots in several incidence and mortality studies. ${ }^{1-7}$ In some of these studies the increased risk of melanoma has been related to exposure to cosmic radiation, ${ }^{56}$ and in a Norwegian study there was statistically significant exposure-response relation between cumulated radiation dose and malignant melanoma. ${ }^{7}$ Non-melanoma skin cancer has also been found in excess among Canadian pilots (mainly basal cell carcinomas) ${ }^{1}$ and among Danish and Norwegian pilots. ${ }^{5} 7$

Three studies on cabin attendants showed an increased incidence of malignant melanoma: a non-significant excess in a Finnish study, ${ }^{8}$ and a significant excess in the studies from Iceland and the USA. ${ }^{10}$

In the previous studies on Icelandic pilots and cabin attendants, standardised incidence ratios for malignant melanoma were 10 and 3 respectively. ${ }^{6}$

Jets with a cruising altitude of 30000 feet or higher have now been in commercial use for more than 30 years, which means higher exposure to cosmic radiation than in non-jet aircraft. In studies on aircrews the occupational exposure of greatest concern was cosmic radiation. ${ }^{1-10}$ Cosmic radiation is a mixture of gamma rays and neutrons, ${ }^{11}$ with the neutrons constituting $30-60 \%$ of the radiation. In 1999, the International Agency for Research on Cancer (IARC) concluded that there is sufficient evidence that neutrons are carcinogenic to humans; ${ }^{12}$ this conclusion was reached on the basis of results from studies on animals only, as the studies on humans were considered inadequate.

The challenge for future epidemiological studies on the effects of neutrons is to identify which human cancers are involved and to elucidate the exposure-response relation. Pilots and cabin attendants should be considered in this context. The exposure of aircrews has been studied carefully; the annual ionising radiation dose sustained by pilots and cabin attendants in their professions is in the range
2-9 mSv. ${ }^{11}{ }^{13} 14$ This dose, which is additional to the background radiation of the general population, is considered low and within the limits for occupational exposure to radiation of non-pregnant adults. However, these estimates of the dose are based on the traditional weighting factors of relative biological effectiveness of neutrons, which according to the IARC monograph are unknown for humans. ${ }^{12}$ Aircrews have a complicated exposure, where different occupational or lifestyle related exposure factors have been considered possible confounders to the effect of cosmic radiation. ${ }^{15}$ Aircrew exposure to UV radiation has not yet been documented, although information on the increased risk of non-melanoma and melanoma skin cancers among them has been accumulating for more than 10 years. The aircrews' potential exposure to UV radiation in a magnitude that would explain the increased skin cancer risk will have to occur during their leisure time, as UV radiation does not penetrate into the cockpit. ${ }^{16}$ To our knowledge this is the first study on sun exposure of aircrews.

The aim of this study was to evaluate whether a difference in the prevalence of risk factors for malignant melanoma in a random sample of the population and among pilots and cabin attendants could explain the increased incidence of malignant melanoma, which had been found in previous studies of aircrews.

\section{METHODS}

Information on the aircrews was obtained from the pilots and cabin crew associations, and the two airline companies, Icelandair and Air Atlanta. These cohorts have been described in detail in previous publications; ${ }^{6}{ }^{9}$ all persons in the studies were residents of Iceland. The cohorts were compared with the national population register (National Registry) and vital status and address in Iceland were achieved for every cohort member. Since 1951 all residents of Iceland are included in the National Registry and have had a unique personal 
identification number allowing automatic and accurate record linkages. A random sample twice as large of the same age and gender proportions as the aircrews was selected from the National Registry. In the previous studies on pilots and cabin attendants, ${ }^{69}$ cancer incidences were compared with the standardised incidences of the general population; thus a random sample of the population was considered appropriate in the present study.

Both the aircrews and the sample of the population received a questionnaire by mail. The questionnaires collected information on known risk factors, such as hair colour, eye colour, freckles, and number of naevi. There were questions on family history of skin cancer and naevi, skin type, history of severe sunburn both before and after the age of 19, use of sunbeds, use of sunscreen, number of sunny vacations, and travel abroad. The questions were taken, with some modification, from previous studies on melanoma risk. ${ }^{17} 18$

We estimated the impact of risk factors on differences of malignant melanoma rates for the aircrews versus the sample of the population using the method described by Axelson and Steenland. ${ }^{19}$ In our previous study on cabin attendants we used these techniques for indirect adjustment for breast cancer rate ratio due to differences of reproductive factors ${ }^{9}$; others have used them for adjustment of smoking differences. ${ }^{20}$ In these calculations, we assumed, for example, that the malignant melanoma rate ratios for more than 20 sunny vacation, 11-20 sunny vacations, 1-10 sunny vacations, and never sunny vacations were $5,3,2$, and 1 , respectively, taking into consideration risks found in previous studies. ${ }^{17}{ }^{18}$ The expected or predictive malignant melanoma rate ratio between aircrew and the population sample due to differences in number of sunny vacations alone is $I_{\text {aircrew }} / I_{\text {population sample, where the malignant mela- }}$ noma rates for the aircrew $\left(\mathrm{I}_{\text {aircrew }}\right)$ and for the population sample ( $\left.\mathrm{I}_{\text {population sample }}\right)$ are each a weighted average of the rates for those with no sunny vacation (rate $={ }^{*} \mathrm{I}_{0}$ ), for those with $1-10$ sunny vacation $\left(\right.$ rate $=2 * \mathrm{I}_{0}$ ), for those with 11-20 sunny vacations (rate $=3^{*} \mathrm{I}_{0}$ ), and for those with more than 20 sunny vacations $\left(\right.$ rate $=5 * I_{0}$ ), as follows: $\mathrm{I}_{\text {aircrew }}=\mathrm{I}_{0}(1)\left(\%\right.$ never sunny vacation $\left.{ }_{\text {aircrew }}\right)+\mathrm{I}_{0}(2)$ (\%1-10 sunny vacation aircrew $)+\mathrm{I}_{0}(3)(\% 11-20$ sunny vacation $\left._{\text {aircrew }}\right)+\mathrm{I}_{0}(5)(\%$ more than 20 sunny vacation aircrew $)$, and $\mathrm{I}_{\text {population sample }}=\mathrm{I}_{0}(1)(\%$ never sunny vacation population sample $)$ $+\mathrm{I}_{0}(2)\left(\% 1-10\right.$ sunny vacation population sample $\left._{1}\right)+\mathrm{I}_{0}(3)(\% 1 \mathrm{l}-20$ sunny vacation population sample $)+\mathrm{I}_{0}(5)(\%$ more than 20 sunny vacation $_{\text {population sample }}$ ).

Permission was obtained from the Data Protection Authority and National Bioethics Committee to conduct this study and to use the registers. Consent was obtained from all participants.

\section{RESULTS}

A total of 5369 persons were eligible for the study. Of these, 3013 responded $(56.1 \%)$. Among the pilots the participation rate was $72.0 \%$ (average age 53, range $28-87$ ) and among the male population sample the participation rate was $44.0 \%$ (average age 46, range 24-87). The corresponding figures for cabin attendants was $65.4 \%$ (average age 46, range $25-74$ ) and for the female population sample $57.3 \%$ (average age 43 , range $21-73$ )

Table 1 shows the answers of male pilots and males from the population sample. The percentage of constitutional factors was similar among the pilots and the sample. The proportion of pilots who had a history of severe sunburn both before and after the age of 19 was higher than among males in the population sample. On the other hand, $5.7 \%$ of the males in the population had used sunbeds/sunlamps more than 100 times; the corresponding figure was $0.8 \%$ for the pilots. Pilots had more often used sunscreen than other males. Pilots had more often had more than 20 sunny vacations than had the male population sample; figures were $22.6 \%$ and $5.1 \%$ respectively. Understandably the pilots had more often travelled abroad. The frequency of yes answers on skin cancer or many naevi among relatives was higher among pilots than other males.

Table 2 shows the answers of cabin attendants and females in the population sample. As in the case of the men, the constitutional factors were of similar frequency in the two groups. History of severe sunburn both before and after the age of 19 was more frequent among cabin attendants than other women, as was the use of sunbeds, although the difference was small. Cabin attendants, like pilots, had more often used sunscreen and more often taken sunny vacations than other women; the percentages for more than 20 sunny vacations for the cabin attendants and the female population sample were $16.7 \%$ and $2.7 \%$ respectively.

Table 3 shows the predictive value of selected questions when pilots and cabin attendants were compared with the population, and also the selected risk ratios for different risk categories. The predictive values for history of sunburn and use of sunbeds were generally low, ranging from 0.85 to 1.03 . The predictive values were highest for sunny vacations, 1.34 for cabin attendants and 1.36 for pilots; however, values for use of sunscreen were 0.85 for cabin attendants and 0.88 for pilots.

\section{DISCUSSION}

The difference in constitutional and behavioural risk factors for malignant melanoma between the aircrews and the population sample was not substantial. The greatest difference was found for prevalence of sunny vacation where the aircrews had higher prevalence.

The standardised incidence ratios for malignant melanoma were 10 for pilots ${ }^{6}$ and 3 for cabin attendants ${ }^{9}$ in the previous studies, while the highest predictive values, according to the method of Axelson and Steenland, ${ }^{19}$ were for sunny vacations, 1.36 and 1.34 respectively. All the predictive values for others risk factors were lower, and some were less than 1 . Thus it is unlikely that the increased incidence of malignant melanoma observed in these studies can be explained solely by excessive sun exposure of the aircrews compared to the general population, which has been the standard of comparison in the previous studies. ${ }^{69}$

When reflecting on whether ionising radiation may cause malignant melanoma, it is necessary to bear in mind that malignant melanoma is first and foremost a disease of people of European/Caucasian origin; it is rare in Blacks and Asians ${ }^{18}$ and because of high survival rate, incidence and case-control studies have a clear advantage over mortality studies. In the literature there are few studies indicating a relation between ionising radiation and incidence of malignant melanoma; however, we are not aware of a convincing negative study on such a relation-that is, a large, unbiased study in a susceptible population which has shown similar rates in exposed and unexposed groups with narrow confidence intervals.

There are some studies indicating an association between radiation exposure and malignant melanoma. ${ }^{21-25}$ Of these, the studies on employees of the Lawrence Livermore National Laboratory (LLNL) are of greatest interest. ${ }^{22} 232526$ All these studies except one ${ }^{26}$ have shown an association between radiation exposure and malignant melanoma. The authors of that study describe matches on several exposure related variables, which may have influenced their results. From the radiation laboratory at Los Alamos, which had similar activities as LLNL, an incidence study based on six $\operatorname{cases}^{27}$ and a case-control study with 15 male and 5 female cases ${ }^{28}$ have been published. These studies ${ }^{27}$ have not found a clear 


\begin{tabular}{|c|c|c|c|c|c|c|}
\hline & & \multicolumn{2}{|c|}{ Pilots ( $n=239$ ) } & \multicolumn{2}{|c|}{$\begin{array}{l}\text { Population sample } \\
\text { ( } \mathrm{n}=454 \text { ) }\end{array}$} & \multirow[b]{2}{*}{ p value } \\
\hline & & n & $\%$ & n & $\%$ & \\
\hline 1. & Have ever had freckles & 101 & 42.3 & 189 & 41.6 & 0.87 \\
\hline 2. & Red hair colour & 15 & 6.3 & 26 & 5.7 & 0.77 \\
\hline 3. & Blue or green eye colour & 219 & 91.6 & 395 & 87.0 & 0.07 \\
\hline \multirow[t]{4}{*}{4.} & Number of naevi & & & & & \\
\hline & $0-20$ & 159 & 66.5 & 335 & 73.8 & \\
\hline & $21-100$ & 67 & 28.0 & 87 & 19.2 & \\
\hline & More than 100 & 13 & 5.4 & 19 & 4.2 & $<0.05$ \\
\hline \multirow[t]{5}{*}{5.} & Skin reactions when sunbathing & & & & & \\
\hline & Always burn, never tan & 11 & 4.6 & 15 & 3.3 & \\
\hline & Always burn, occasionally tan & 28 & 11.7 & 55 & 12.1 & \\
\hline & Occasionally burn, always tan & 176 & 73.6 & 306 & 67.4 & \\
\hline & Never burn, always tan & 21 & 8.8 & 67 & 14.8 & $<0.20$ \\
\hline \multirow[t]{4}{*}{6.} & $\begin{array}{l}\text { History of severe sunburn after the } \\
\text { age of } 19\end{array}$ & & & & & \\
\hline & Never & 28 & 11.7 & 88 & 19.4 & \\
\hline & $1-5$ times & 143 & 59.8 & 265 & 58.4 & \\
\hline & More than 5 times & 68 & 28.5 & 97 & 21.4 & $<0.02$ \\
\hline \multirow[t]{4}{*}{7.} & $\begin{array}{l}\text { History of severe sunburn } \\
\text { before the age of } 19\end{array}$ & & & & & \\
\hline & Never & 69 & 28.9 & 147 & 32.4 & \\
\hline & $1-5$ times & 125 & 52.3 & 220 & 48.5 & \\
\hline & More than 5 times & 42 & 17.6 & 75 & 16.5 & $<0.70$ \\
\hline \multirow[t]{5}{*}{8.} & Use of sunbeds/sunlamps & & & & & \\
\hline & Never & 114 & 47.7 & 163 & 35.9 & \\
\hline & $1-10$ times & 69 & 28.9 & 136 & 30.0 & \\
\hline & $10-100$ times & 55 & 23.0 & 129 & 28.4 & \\
\hline & More than 100 times & 2 & 0.8 & 26 & 5.7 & $<0.001$ \\
\hline \multirow[t]{4}{*}{9.} & Use of sunscreen & & & & & \\
\hline & Never & 35 & 14.6 & 124 & 27.3 & \\
\hline & Occasionally & 135 & 56.5 & 265 & 58.4 & \\
\hline & Always & 69 & 28.9 & 61 & 13.4 & $<0.001$ \\
\hline \multirow[t]{5}{*}{10.} & Sunny vacation & & & & & \\
\hline & Never & 24 & 10.0 & 106 & 23.3 & \\
\hline & $1-10$ times & 127 & 53.1 & 283 & 62.3 & \\
\hline & $11-20$ times & 34 & 14.2 & 41 & 9.0 & \\
\hline & More than 20 times & 54 & 22.6 & 23 & 5.1 & $<0.001$ \\
\hline \multirow[t]{5}{*}{11.} & Travel abroad & & & & & \\
\hline & Never & 4 & 1.7 & 37 & 8.1 & \\
\hline & $1-5$ times & 16 & 6.7 & 181 & 39.9 & \\
\hline & 6-20 times & 39 & 16.3 & 165 & 36.3 & \\
\hline & More than 20 times & 180 & 75.3 & 68 & 15.0 & $<0.001$ \\
\hline 12. & Skin cancer among relatives: yes & 25 & 10.5 & 26 & 5.7 & 0.02 \\
\hline 13. & Many naevi among relatives: yes & 61 & 25.5 & 107 & 23.6 & 0.57 \\
\hline
\end{tabular}

association between radiation and the risk of malignant melanoma.

There are two recent incidence studies of atomic bomb survivors in Japan. One found 11 cases of malignant melanoma in a series of 140 skin cancer cases. ${ }^{29}$ The other study found 10 cases of malignant melanoma in the combined populations from Hiroshima and Nagasaki with large excess relative risk point estimate, but a wide confidence interval. ${ }^{30}$ These indications of an association are important in view of the low background incidence of malignant melanoma in Japan.

Studies on participants of nuclear tests and civilians situated downwind of such tests have indicated an increased incidence of malignant melanoma. ${ }^{31-33}$ However, they have been found to be defective because of methodological weaknesses ${ }^{33}{ }^{34}$ or have included few cases and had wide confidence intervals. ${ }^{31} 32$

Studies evaluating cancer risk in patients treated with radiotherapy are often complicated by primary disease and other treatment, particularly chemotherapy. Case reports of malignant melanoma in patients receiving radiotherapy only are numerous, including one case treated with neutron beam therapy. ${ }^{35}$ As an example, two studies in cohorts surviving testicular cancer showed a significant excess of malignant melanoma following radiotherapy. ${ }^{36}{ }^{37}$ One of these studies showed a definite excess of malignant melanoma following radiotherapy only, ${ }^{36}$ while the other had difficulties differentiating between radiotherapy, chemotherapy, and other factors which may be involved. ${ }^{37}$

Based on evidence from studies on the relation of ionising radiation and non-melanoma skin cancer, a joint carcinogenic effect of ionising radiation and UV radiation has been suggested and discussed, ${ }^{30}$ and it is biologically plausible to expect the same phenomenon in the case of malignant melanoma if ionising radiation (cosmic radiation) can induce malignant melanoma. The pilots and the cabin attendants of previous cohort studies in Iceland ${ }^{69}$ were carefully informed about the results immediately after publication. Because of public health and ethical perspective we then stressed the importance of avoiding sunshine or other sources of UV radiation as these are known causes of malignant melanoma. It is not known whether this has affected the participation rate in the present study or the answers to the questionnaire, thus possibly giving rise to bias.

Studies of aircrews have raised the question of the importance of the type of radiation involved, as the increased risk of malignant melanoma is consistent and high in many studies, ${ }^{1-10}$ and there are indications of a trend of increasing 
Table 2 Answers to questionnaire for assessment of malignant melanoma risk among cabin attendants and a sample of the population (all female)

\begin{tabular}{|c|c|c|c|c|c|c|}
\hline & & \multicolumn{2}{|c|}{$\begin{array}{l}\text { Cabin attendants } \\
(\mathrm{n}=856)\end{array}$} & \multicolumn{2}{|c|}{$\begin{array}{l}\text { Population sample } \\
\text { ( } n=1464 \text { ) }\end{array}$} & \multirow[b]{2}{*}{ p value } \\
\hline & & $n$ & $\%$ & $n$ & $\%$ & \\
\hline 1. & Have ever had freckles & 507 & 59.3 & 905 & 61.8 & 0.22 \\
\hline 2. & Red hair colour & 39 & 4.6 & 103 & 7.0 & 0.02 \\
\hline 3. & Blue or green eye colour & 741 & 86.6 & 1301 & 88.9 & 0.10 \\
\hline \multirow[t]{4}{*}{4.} & Number of naevi & & & & & \\
\hline & $0-20$ & 398 & 46.5 & 794 & 54.2 & \\
\hline & $21-100$ & 339 & 39.6 & 491 & 33.5 & \\
\hline & More than 100 & 107 & 12.5 & 147 & 10.0 & $<0.001$ \\
\hline \multirow[t]{5}{*}{5.} & Skin reactions when sunbathing & & & & & \\
\hline & Always burn, never tan & 11 & 1.3 & 56 & 3.8 & \\
\hline & Always burn, occasionally tan & 87 & 10.2 & 223 & 15.2 & \\
\hline & Occasionally burn, always tan & 644 & 75.3 & 924 & 63.1 & \\
\hline & Never burn, always tan & 105 & 12.3 & 228 & 15.6 & $<0.001$ \\
\hline \multirow[t]{4}{*}{6.} & $\begin{array}{l}\text { History of severe sunburn after the } \\
\text { age of } 19\end{array}$ & & & & & \\
\hline & Never & 103 & 12.0 & 243 & 16.6 & \\
\hline & $1-5$ times & 522 & 61.1 & 880 & 60.1 & \\
\hline & More than 5 times & 227 & 26.5 & 325 & 22.2 & $<0.01$ \\
\hline \multirow[t]{4}{*}{7.} & $\begin{array}{l}\text { History of severe sunburn } \\
\text { before the age of } 19\end{array}$ & & & & & \\
\hline & Never & 215 & 25.1 & 428 & 29.2 & \\
\hline & $1-5$ times & 490 & 57.3 & 744 & 50.8 & \\
\hline & More than 5 times & 136 & 15.9 & 253 & 17.3 & $<0.02$ \\
\hline \multirow[t]{5}{*}{8.} & Use of sunbeds/sunlamps & & & & & \\
\hline & Never & 81 & 9.5 & 179 & 12.2 & \\
\hline & $1-10$ times & 236 & 27.6 & 457 & 31.2 & \\
\hline & $10-100$ times & 476 & 55.7 & 700 & 47.8 & \\
\hline & More than 100 times & 62 & 7.3 & 123 & 8.4 & $<0.01$ \\
\hline \multirow[t]{4}{*}{9.} & Use of sunscreen & & & & & \\
\hline & Never & 27 & 3.2 & 145 & 9.9 & \\
\hline & Occasionally & 357 & 41.8 & 800 & 54.6 & \\
\hline & Always & 470 & 55.0 & 516 & 35.2 & $<0.001$ \\
\hline \multirow[t]{5}{*}{10.} & Sunny vacation & & & & & \\
\hline & Never & 34 & 4.0 & 288 & 19.7 & \\
\hline & $1-10$ times & 527 & 61.6 & 1011 & 69.1 & \\
\hline & $11-20$ times & 150 & 17.5 & 122 & 8.3 & \\
\hline & More than 20 times & 144 & 16.8 & 40 & 2.7 & $<0.001$ \\
\hline \multirow[t]{5}{*}{11.} & Travel abroad & & & & & \\
\hline & Never & 5 & 4.0 & 114 & 7.8 & \\
\hline & $1-5$ times & 108 & 12.6 & 687 & 46.9 & \\
\hline & 6-20 times & 280 & 32.7 & 545 & 37.2 & \\
\hline & More than 20 times & 459 & 53.7 & 105 & 7.2 & $<0.001$ \\
\hline 12. & Skin cancer among relatives: yes & 86 & 10.1 & 128 & 8.7 & 0.30 \\
\hline 13. & Many naevi among relatives: yes & 326 & 38.1 & 547 & 37.4 & 0.73 \\
\hline
\end{tabular}

incidence by exposure (cumulated dose of cosmic radiation). ${ }^{5-79}$ According to English and colleagues, ${ }^{18}$ an exposureresponse relation between sunlight and malignant melanoma has only rarely been observed, ${ }^{38}$ partly because of the importance of the pattern of sun exposure, making the association between cumulated dose of cosmic radiation and incidence of malignant melanoma peculiar. The interpretations of the authors of the Norwegian and the Danish studies ${ }^{5}$ were not based on evidence on sun exposure but they suggested, in guarded terms, that the observed trend may be due to excessive sunbathing of the pilots, considering that those with the longest professional careers had had the greatest opportunity for sunny vacations. If the leisure time sun exposure induces the excess of malignant melanoma, ${ }^{57}$ that argument presumes that the cumulated dose of cosmic radiation correlates almost completely with the leisure time sun exposure. The location of the malignant melanoma on the trunk and limbs was thought to indicate that they were induced by sun exposure rather than cosmic radiation. ${ }^{5}$ It is well known that UV radiation is associated with malignant melanoma on trunk and limbs; ${ }^{18}$ however, that fact does not give the authors reason to conclude that cosmic radiation would not induce skin cancer on the trunk and limbs, or that cosmic radiation and UV radiation would not have a joint carcinogenic effect. One can only speculate whether the findings in the present study are also valid for aircrews and general populations in the other Nordic counties.

The exposure situation of the small Icelandic cohorts of pilots and cabin attendants is different from that of other groups. ${ }^{69}$ The airline companies in Iceland have had regular European routes since 1945 and regular transatlantic routes since $1952 .{ }^{6}$ Since 1971 they have operated jets on all routes. ${ }^{9}$ The schedules for the flights have had Keflavik in Iceland as the hub. The most common destinations in Europe have been Copenhagen, London, Glasgow, Oslo, Stockholm, Hamburg, Luxembourg, and Frankfurt; and the most common destinations in North America have been New York, Boston, Baltimore, Chicago, Minneapolis, Orlando, and Halifax. More than half of the pilots have been flying from Iceland to both America and Europe, ${ }^{6}$ and the cabin attendants have been flying on all routes by turns. ${ }^{9}$ Thus the workforce of the Icelandic airline companies has, according to the CARI programme, ${ }^{14}$ been widely used to estimate radiation dose of aircrews, a higher cumulated dose than for aircrews of airline companies which have many domestic routes in America or on the European continent. ${ }^{11} 1314$ The high 
Table 3 Predictive value (PV) and selected questions from the questionnaire for assessment of malignant melanoma risk when the cohorts of pilots and cabin attendants were compared to a random sample of the population, according to Axelson and Steenland ${ }^{18}$

\begin{tabular}{|c|c|c|c|c|}
\hline & & $\begin{array}{l}\text { Selected } \\
\text { risk ratio }\end{array}$ & $\begin{array}{l}\text { PV for } \\
\text { pilots }\end{array}$ & $\begin{array}{l}\text { PV for } \\
\text { cabin } \\
\text { attendants }\end{array}$ \\
\hline \multirow[t]{2}{*}{2.} & $\begin{array}{l}\text { Red hair colour } \\
\text { Other hair colour }\end{array}$ & $\begin{array}{l}1.5 \\
1\end{array}$ & & \\
\hline & & & 1.00 & 0.99 \\
\hline \multirow[t]{4}{*}{4.} & Number of naevi & & & \\
\hline & $0-20$ & 1 & & \\
\hline & $21-100$ & 1.5 & & \\
\hline & More than 100 & 2.5 & & \\
\hline & Skin reactions when sunbathing & & 1.08 & 1.06 \\
\hline \multirow{4}{*}{5.} & $\begin{array}{l}\text { Always burn, never tan } \\
\text { Alwing }\end{array}$ & 5 & & \\
\hline & Always burn, occasionally tan & 3 & & \\
\hline & Occasionally burn, always tan & 2 & & \\
\hline & Never burn, always tan & 1 & & \\
\hline & & & 1.06 & 0.97 \\
\hline \multirow[t]{5}{*}{6.} & $\begin{array}{l}\text { History of severe sunburn after } \\
\text { the age of } 19\end{array}$ & & & \\
\hline & Never & 1 & & \\
\hline & $1-5$ times & 1.5 & & \\
\hline & More than 5 times & 2.5 & & \\
\hline & & & 1.08 & 1.05 \\
\hline \multirow[t]{5}{*}{7.} & $\begin{array}{l}\text { History of severe sunburn } \\
\text { before the age of } 19\end{array}$ & & & \\
\hline & Never & 1 & & \\
\hline & $1-5$ times & 1.5 & & \\
\hline & More than 5 times & 2.5 & & \\
\hline & & & 1.03 & 1.01 \\
\hline \multirow[t]{4}{*}{8.} & Use of sun beds/sunlamps & & & \\
\hline & Never & 1 & & \\
\hline & $1-10$ times & 2 & & \\
\hline & $10-100$ times & 3 & & \\
\hline & & & 0.85 & 1.03 \\
\hline \multirow{4}{*}{9.} & $\begin{array}{l}\text { Use of sunscreen } \\
\text { Never }\end{array}$ & 3 & & \\
\hline & $\begin{array}{l}\text { Never } \\
\text { Sometimes }\end{array}$ & $\begin{array}{l}3 \\
2\end{array}$ & & \\
\hline & Always & 1 & & \\
\hline & & & 0.88 & 0.85 \\
\hline \multirow[t]{6}{*}{10} & Sunny vacation & & & \\
\hline & Never & 1 & & \\
\hline & $1-10$ times & 2 & & \\
\hline & $11-20$ times & 3 & & \\
\hline & More than 20 times & 5 & & \\
\hline & & & 1.36 & 1.34 \\
\hline
\end{tabular}

proportion of international flights to and from Iceland, located in the north Atlantic, could, if cosmic radiation plays a role, contribute to the high rates of malignant melanoma found in these cohorts. ${ }^{6}{ }^{9}$

In conclusion, no substantial difference was found in the frequency of constitutional factors or exposure to UV radiation as risk factors for malignant melanoma between the aircrew and a sample of the population. Thus it is unlikely that the increased incidence of malignant melanoma found in previous studies of pilots and cabin attendants can be solely explained by excessive sun exposure. There is an urgent need to evaluate further the increased risk of malignant melanoma among aircrew, preferably in prospective studies that control for sun exposure and other risk factors for malignant melanoma. Future studies should also elucidate skin cancer risk among airline passengers, particularly frequent flyers, considering the increase in annual incidence of malignant melanoma in the general population.

\section{ACKNOWLEDGEMENTS}

We thank the staff and the management of Icelandair and Air Atlanta, and the associations of cabin crew and the pilots for their information and for allowing us access to their files.

\section{Authors' affiliations}

V Rafnsson, Department of Preventive Medicine, University of Iceland, Soltun 1, 105 Reykjavik, Iceland

J Hrafnkelsson, Department of Oncology, Landspitali-University Hospital, Reykjavik, Iceland

H Tulinius, Icelandic Cancer Registry, Skogarhlid 8, 105 Reykjavik, Iceland

B Sigurgeirsson, J Hialtalin Olafsson, Department of Dermatology, Landspitali-University Hospital, Reykjavik, Iceland

\section{REFERENCES}

1 Band PR, Spinelli JJ, Ng VTY, et al. Mortality and cancer incidence in a cohort of commercial airline pilots. Aviat Space Environ Med 1990;61:299-302.

2 Vågerö D, Swerdlow AJ, Beral V. Occupation and malignant melanoma: a study based on cancer registration data in England and Wales and in Sweden. Br J Ind Med 1990;47:317-24.

3 Band PR, Le ND, Fang R, et al. Cohort study of Air Canada pilots: mortality, cancer incidence and leukemia risk. Am J Epidemiol 1996;143:137-43.

4 Irvine D, Davies DM. British Airways flightdeck mortality study, 1950-1992. Aviat Space Environ Med 1999;70:548-55.

5 Gundestrup M, Storm HH. Radiation-induced acute myeloid leukemia and other cancers in commercial jet cockpit crew: a population-based cohort study. Lancet 1999;354:2029-31.

6 Rafnsson V, Hrafnkelsson J, Tulinius $\mathrm{H}$. Incidence of cancer among commercial airline pilots. Occup Environ Med 2000;57:175-9.

7 Haldorsen T, Reitan JB, Tveten U. Cancer incidence among Norwegian airline pilots. Scand J Work Environ Health 2000;26:106-11.

8 Pukkala E, Auvinen A, Wahlberg G. Incidence of cancer among Finnish airline cabin attendants, 1967-92. BMJ 1995;311:649-52.

9 Rafnsson V, Tulinius $H$, Jonasson JG, et al. Risk of breast cancer in flight attendants: population-based study (Iceland). Cancer Causes Control 2001;12:95-101.

10 Reynolds $\mathbf{P}$, Cone JE, Layefsky M, et al. Cancer incidence in California flight attendants (United States). Cancer Causes Control 2002;13:317-24.

11 Friedberg W, Faulkner DN, Snyder L, et al. Galactic cosmic radiation exposure and associated health risk for air crew members. Aviat Space Environ Med 1989;60:1 104-8.

12 IARC Working Group on Evaluation of Carcinogenic Risk to Humans. lonizing radiation, Part 1: $x$ - and gamma-radiation, and neutrons, Vol. 75. IARC Monographs on Evaluation of Carcinogenic Risk to Humans. Lyon, France: IARC, 2000.

13 Bagshaw M, Irvine D, Davies DM. Exposure to cosmic radiation of British Airways flying crew on ultralonghaul routes. Occup Environ Med 1996:53:495-8.

14 Nicholas JS, Lackland DT, Butler GC, et al. Cosmic radiation and magnetic field exposure to airline flight crews. Am J Ind Med 1998;34:574-80.

15 Blettner M, Grosche B, Zeeb H. Occupational cancer risk in pilots and flight attendants: current epidemiological knowledge. Radiat Environ Biophys 1998:37:75-80.

16 Diffey BL, Roscoe AH. Exposure to solar ultraviolet radiation in flight. Aviat Space Environ Med 1990;61:1032-5.

17 Westerdahl J, Anderson $\mathrm{H}$, Olsson $\mathrm{H}$, et al. Reproducibility of a selfadministered questionnaire for assessment of melanoma risk. Int J Epidemiol 1996;25:245-51.

18 English DR, Armstrong BK, Kricker A, et al. Sunlight and cancer. Cancer Causes Control 1997:8:271-83.

19 Axelson O, Steenland K. Indirect methods of assessing the effects of tobacco use in occupational studies. Am J Ind Med 1988;13:105-18.

20 Steenland K, Sanderson W. Lung cancer among industrial sand workers exposed to crystalline silica. Am J Epidemiol 2001;153:695-703.

21 Holman CDJ, Armstrong BK, Heenan PJ, et al. The causes of malignant melanoma: results from the West Australian Linos Melanoma Research Project. Recent Results Cancer Res 1986;102:18-37.

22 Austin DF, Reynolds P. Occupation and malignant melanoma of the skin. Recent Results Cancer Res 1986;102:98-107.

23 Schwartzbaum JA, Setzer RW, Kupper LL. Exposure to ionizing radiation and risk of cutaneous malignant melanoma. Search for error and bias. Ann Epidemiol 1994;4:487-96.

24 Pion IA, Rigel DS, Garfinkel L, et al. Occupation and risk of malignant melanoma. Cancer 1995; 15(suppl):637-44.

25 Austin DF, Reynolds P. Investigating of an excess of melanoma among employees of the Lawrence Livermore National Laboratory. Am J Epidemiol 1997; 145:524-31.

26 Moore DH, Patterson HW, Hatch F, et al. Case-control study of malignant melanoma among employees of the Lawrence Livermore National Laboratory. Am J Ind Med 1997;32:377-91.

27 Acquavella JF, Tietjen GL, Wilkinson GS, et al. Malignant melanoma incidence at the Los Alamos National Laboratory. Lancet 1982;1:883-4.

28 Acquavella JF, Wilkinson GS, Tietjen GL, et al. A melanoma case-control study at the Los Alamos National Laboratory. Health Phys 1983;45:587-92.

29 Sadamori N, Mine M, Honda T. Incidence of skin cancer among Nagasaki atomic bomb survivors. J Radiat Res 1991;2(suppl):217-25.

30 Ron $\mathrm{E}$, Preston $\mathrm{DL}$, Kishikawa $M$, et al. Skin tumor risk among atomic-bomb survivors in Japan. Cancer Causes Control 1998;9:393-401.

31 Caldwell GG, Kelly D, Zack M, et al. Mortality and cancer frequency among military nuclear test (Smoky) participants, 1957 trough 1979. JAMA 1983;250:620-4. 
32 Darby SC, Kendall GM, Fell TP, et al. Further follow up of mortality and incidence of cancer in men from the United Kingdom who participated in the United Kingdom's atmospheric nuclear weapon tests and experimental programmes. BMJ 1993:307:1530-5.

33 Johnson $\mathrm{CJ}$. Cancer incidence in an area of radioactive fallout downwind from Nevada test site. JAMA 1984;251:230-6.

34 Lyon JL, Schuman KL. Radioactive fallout and cancer [letter]. JAMA 1984;252:1854-5.

35 Waxler B. Malignant melanoma in patient who received neutron beam therapy. Lancet 1984;1:904-5.
36 Fosså SD, Langmark F, Aass N, et al. Second non-germ cell malignancies after radiotherapy of testicular cancer with or without chemotherapy. Br J Cancer 1990;61:639-43.

37 Travis LB, Curtis RE, Storm H, et al. Risk of second malignant neoplasms among long-term survivors of testicular cancer. J Natl Cancer Inst 1997;89:1429-39.

38 Elwood JM, Callagher RP, Hill GB, et al. Cutaneous melanoma in relation to intermittent and constant sun exposure-the Western Canada Melanoma Study. Int J Cancer 1985;35:427-33.

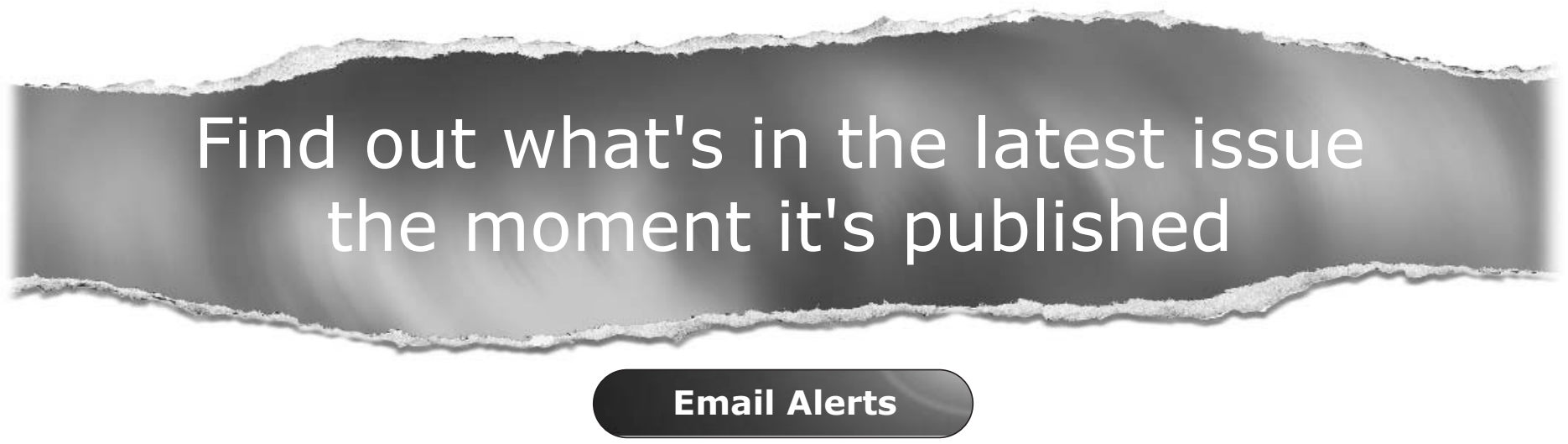

Sign up to receive the table of contents by email every month. You can select from three alerts: Table of Contents (full), TOC Awareness (notice only); Occupational and Environmental Medicine related announcements. 